\title{
Las cuentas de la canonización de Santo Tomás de Villanueva
}

The accounts of the canonization of St. Thomas of Villanova

\author{
Dr. F. Javier CAMPOS Y FERNÁNDEZ DE SEVILLA \\ Real Centro Universitario \\ "Escorial-María Cristina" \\ San Lorenzo del Escorial
}

Resumen: Analizamos en este trabajo el proceso de canonización de Santo Tomás de Villanueva a mediados del siglo XVII, los trámites y gastos ocasionados, la financiación y las irregularidades que se dieron con el dinero que provenía de donativos y limosnas hasta aclarar las cuentas en las que estuvieron interesados Felipe IV, el Nuncio en España y Alejandro VII.

Abstract: In this work we analyze the process of canonization of St. Thomas de Villanova in the mid-seventeenth century, the procedures and expenses incurred, as well as the financing and irregularities that occurred with the money that came from donations and alms, clarifying the accounts in which Philip IV, the Nuncio in Spain and Pope Alexander VII were interested.

Palabras claves: Proceso de canonización de Santo Tomás de Villanueva, Felipe III y Felipe IV, Urbano VIII, Alejandro VII, Gaspar de Sobremonte, y los agustinos fray Juan Belda, fray Sebastián García, fray Marco Antonio Mascarós, fray Buenaventura Fuster, fray Andrés Aznar, fray Tomás Figuerola.

Keywords: Process of canonization of St. Thomas de Villanova, Philip III and Philip IV, Pope Urban VIII, Alexander VII, Gaspar de Sobremonte, and the Augustinians Friar Juan Belda, Fr. Sebastian Garcia, Fr. Marco Antonio Mascaros, Fr. Buenaventura Fuster, Fr. Andres Aznar, Fr. Thomas Figuerola.

\section{Sumario:}

I. El comienzo del proceso de glorificación.

II. 1622: "Ha quedado afuera por pobre". 
III. Falta dinero del "Arca del Santo".

IV. Se reactiva el proceso y se pide limosna para la canonización.

V. Intervienen el rey y la nunciatura.

VI. Arreglo final.

VII. Apéndice.

Recibido: septiembre de 2019.

Aceptado: noviembre de 2019. 


\section{EL COMIENZO DEL PROCESO DE GLORIFICACIÓN}

Aunque la santidad se mueve en el ámbito de lo sagrado y espiritual primero hay que demostrar que el/la venerable es merecedor de esa distinción porque su vida se ajustó a las exigencias que la Iglesia tiene establecidas como requisito obligatorio y por las cuales se prueba y reconoce que el candidato/a ha ejercido en su vida unas virtudes en grado sumo que pueden ser puestas a consideración y práctica por parte del pueblo cristiano, que era lo que se había establecido en el concilio de Trento:

"Manda el santo Concilio a todos los Obispos, y demás personas que tienen el cargo y obligación de enseñar, que instruyan con exactitud a los fieles ante todas cosas, sobre la intercesión e invocación de los santos, honor de las reliquias, y uso legítimo de las imágenes (...) enseñándoles que los santos que reinan juntamente con Cristo, ruegan a Dios por los hombres; que es bueno y útil invocarlos humildemente, y recurrir a sus oraciones, intercesión, y auxilio para alcanzar de Dios los beneficios por Jesucristo su hijo, nuestro Señor"1.

Una vez que se cree que así fue en el caso que se trate se inicia el proceso oficial, primero en la respectivas diócesis donde había vivido, en las que se recababa información super vita et virtutibus et fama sanctitatis et signorum, y super martyrio, para lo que se nombraba un comisario y un postulador de la causa, y uno o varios notarios o escribanos eclesiásticos que tomaban, bajo juramento de decir la verdad, las correspondientes declaraciones de los testigos. Finalizada esa fase se enviaba la documentación a la Sagrada Congregación de Ritos y comenzaba la fase romana.

Para todo este procedimiento hace falta dinero, bastante, porque además de los gastos ordinarios de personal y gestión, en el caso de la canonización hace falta dar a conocer lo más que se pueda al beato/a, lo que significa que se han tenido que encargar a artista que graben su imagen e imprimir láminas

\footnotetext{
${ }^{1}$ Decreto sobre la invocación, la veneración y las reliquias de los santos, Concilio de Trento, Ses. XXV (3-XII-1563).
} 
y estampas con su efigie; lo mismo a escritores para que hagan biografías donde cuenten sus virtudes y sus milagros. Mejor si se pintan lienzos y se tallan imágenes. Con esos gastos materiales había que contar al iniciar el proceso y planificar los pasos que había que dar para buscar limosnas y donativos que financiasen el proyecto.

Para el caso que nos ocupa de Santo Tomás de Villanueva, agustino y arzobispo de Valencia, tenemos fundamentalmente a la Provincia agustina de la Corona de Aragón, y subsidiariamente a la Provincia de Castilla, por una parte, y por otra, las instituciones valencianas, eclesiásticas y civiles: el Cabildo metropolitano, la Ciudad y Reino. Todo ello bajo el respaldo formal de la de la Orden de San Agustín, la Corona de España -que tuvo un claro protagonismo-, y el Consejo de Aragón por cuestión territorial y competencia jurisdiccional.

Teniendo en cuenta el ritmo del correr el tiempo en los dicasterios de la Curia Romana el proceso de beatificación del siervo de Dios fray Tomás de Villanueva discurrió con cierta rapidez ${ }^{2}$, incluyendo el proceso diocesano de Valencia y Villanueva de los Infantes ${ }^{3}$, y ciudades de Castilla ${ }^{4}$.

Así tendríamos el siguiente calendario:

2 Proceso de beatificación, Archivo Secreto Vaticano, Ritos (en adelante, ASVR), ms. 3632: Proceso de la vida y milagros del de felice memoria fray Don Thomas de Villanueva; Archivo Histórico Nacional, en adelante AHN,Universidades,L.1099,N4 (fols. 25-35); Processo di canonizzazione del beato Tommaso di Villanova, ), Biblioteca Angelica de Roma (en adelante, BAR), ms. 105, cc. 1r-376r; Summarium actionum et virturum venerabilis fratris Thomae a Villanueva ... (1r), BAR, ms. 108, cc, 1r-495v. Agradezco a doña Anna Letizia Di Carlo de la Sec. de Manoscritti e Rari de la Biblioteca Angelica de Roma la ayuda prestada. ACTAS de la Beatificación. Copia de declaraciones algunos testigos de Valladolid y Burgos, 1606. BNM, ms. 1269 , fols. $92-100 \mathrm{v}$.

${ }^{3}$ Processus Valentiae factus..., Archivo Secreto Vaticano (en adelante, ASVR), ms. 3641, 511 fols. Actas del proceso de beatificación. Copia de las declaraciones de los testigos de Valencia y de Villanueva de los Infantes. Manuscrito del Archivo de la Parroquia de San Andrés. Transcripción, estudio y notas, de L. Manrique y F.J. Campos, San Lorenzo del Escorial 2014.

${ }^{4}$ Copia seu transumptum processus executionis Remissoriae in diversis partibus Regni Castellae factae... servi Dei fratris Don Thomae de Villanueva..., ASVR, ms. 3633, 685 fols.; ms. 3634, 685 fols.; ms. 3635, 686 fols.; ms. 3636, 464 fols.; ms. 3638, 1072 fols.; ms. 3639, 1072 fols.; ms. 3640, fols. 1072. ASVR, Processus pro canonizatione Sti. Thomae a Villanova... Traducción italiana, y el último con la carta de los Jueces y Comisarios Apostólicos, mss. 3642 y 3643, 1266 fols. RABASSA, G.G.,Copia seu transumptum processus executionis remissoriae in diversis partibus Regni Castellae fact., ad specialem et particularem inquisitionem formandam super canonizatione bo. me. servi Dei fratris don Thomae de Villanueva, olim professi in Ordine Heremitarum S.ti Augustini, et deinde archiepiscopi Valentini (1r), BAR, ms. 205, cc. 7r$18 \mathrm{v} ; 1 \mathrm{r}-685 \mathrm{r}$. Actas de proceso de beatificación. Copia de declaraciones algunos testigos de Valladolid y Burgos, 1606 con el relato de unos milagros y curaciones en Valencia. Biblioteca Nacional, Madrid, ms. 1269, fols. 92-100v. 
- 1601. Petición por parte de los agustinos de Valencia de la apertura del proceso al arzobispo San Juan de Ribera: 10 de octubre.

- 1601. Apertura oficial de del proceso diocesano; nombramiento de don Cristóbal Colón como visitador de la diócesis y de don Juan Micón como notario: 10 de octubre.

- 1601/1604. Deposiciones de 31 testigos en Valencia: del 13 de noviembre al 10 de enero, respect.

- 1602. Los agustinos de Valencia nombran al P. Domingo Comisano procurador para hacer la información de la Vida y Virtudes del P. fray Tomás de Villanueva: 1 de junio.

- 1602. Deposiciones de 49 testigos en Villanueva de los Infantes ante el procurador P. Comisano: del 17 de junio al 15 de julio.

- 1603. Exhumación y traslado de los restos en la misma iglesia del convento del Socorro: 21 de noviembre.

- 1606. Deposiciones de testigos en Burgos y Valladolid ante el procurador P. Comisano: julio en ambas ciudades.

- 1608. Los estamentos de Valencia, Ciudad y Reino, nombran al P. fray Juan Belda procurador de la causa de la beatificación en Roma: 13 de septiembre.

- 1609. Paulo V autoriza que la Sagrada Congregación de Ritos nombre una comisión para el proceso romano de la canonización: 26 de noviembre.

- 1610. Se nombra al P. fray Miguel Salón procurador de la causa de Beatificación: 10 de julio.

- 1610: Felipe III comunica a su embajador en Roma que el Provincial agustino le informa que se han presentado las informaciones de la causa en la Santa Sede y que el proceso está bien sustanciado: 8 de octubre.

- 1610. Se envían las letras remisoriales de la vida del beato Tomás de Villanueva: 20 de septiembre.

- 1611. El Capítulo de la Provincia de Aragón confirma al P. Belda como procurador general en Roma de la causa de beatificación: 28 de abril.

- 1614. El Capítulo de la Provincia de Aragón confirma al P. Belda en su cargo, y a los PP. Miguel Salón y Sebastián García en sus puestos en la misma causa: 19 de abril.

- 1617. El Capítulo de la Provincia de Aragón confirma al P. Belda en su cargo: 15 de abril. 
Tras la finalización de los trámites diocesanos la Provincia agustina de la Corona de Aragón nombró procurador de la causa en Roma al P. Juan Belda, que fue ratificado también como representante de los estamentos de la Ciudad y Reino de Valencia 5 .

Superadas todas las pruebas y requisitos se procedió a la beatificación el 7 de octubre de 1618:

"Paulo Papa V. Para perpetua memoria (...) por autoridad Apostólica, $\mathrm{y}$ tenor de las presentes concedemos perpetuamente, y otorgamos, que el dicho de buena memoria Tomás de Villanueva, de aquí adelante pueda ser llamado Beato; y que todos los años a diez y ocho de Septiembre en todo el Reino de Valencia por los religiosos de la misma Orden de san Agustín, así Frayles como Monjas, y en la Ciudad de valencia donde su cuerpo se afirma descansar, y en la Diócesis de Valencia, de quien, como está dicho, fue Arzobispo por tiempo de once años, por todos los Frayles y Monjas , y también los Presbyteros, y Clérigo seculares respectivamente de él, como Beato, conforme las rúbricas del Breviario, y Misal Romano, de Confesor Pontífice se pueda libre y lícitamente rezar Oficio, y celebrar Misa"6.

\section{1622: "HA QUEDADO AFUERA POR POBRE"}

La marcha del proceso de canonización sufrió un duro golpe porque estando todo terminado el beato fray Tomás de Villanueva no entró en la gran canonización del 12 de marzo 1622 efectuada por Gregorio $\mathrm{XV}^{7}$.

\footnotetext{
${ }^{5}$ CAMPOS Y FERNÁNDEZ DE SEVILLA, F.J., "El agustino fray Juan Belda procurador de la Beatificación del siervo de Dios don Tomás de Villanueva, arzobispo de Valencia", en $L a$ Iglesia y el Mundo Hispánico en tiempos de Santo Tomás de Villanueva (1486-1555), San Lorenzo del Escorial 2018, pp. 443-464; IDEM, "La empresa de hacer un santo. Religión, política y economía en la causa de Santo Tomás de Villanueva", en IDEM, Estudios sobre Santo Tomás de Villanueva y su tiempo. IV Centenario de la beatificación, en Ibid, pp. 465-504; VINCENT-CASSY, C., "Luchar por su santo. Rivalidades entre las órdenes religiosas en torno a las canonizaciones en el siglo XVII", en BELTRÁN, J.; HERNÁNDEZ, B., y MORENO, D. (eds.), Identidades y fronteras culturales en el mundo ibérico de la Edad Moderna, Barcelona 2016, pp. 179-192.

${ }^{6}$ SALÓN, M., Libro de la Vida y Milagros de Santo Tomás de Villanueva..., Madrid 1793, p. 398; MARTÍNEZ DE LA VEGA, J., Solemnes y grandiosas fiestas que la noble y leal ciudad de Valencia ha hecho por la Beatificación de su Santo Pastor y Padre D. Thomas de Villanueva, Valencia 1620, pp. 32-34.

${ }^{7}$ Los santos fueron: San Isidro, San Ignacio, San Francisco Javier, Santa Teresa más el florentino San Felipe Neri. Breve de la canonización, en FUENTE, V. de la, Escritos de Santa Teresa, Madrid 1862, t. II, p. 432, BAE, LV; "Relación de lo que se hizo en Roma a la Canonización de los Santos...", ej. Biblioteca Nacional, Madrid, V. C., 226/22.
} 
Fray Juan Belda experimentó en primera persona los efectos de esa canonización porque era el responsable de la marcha del proceso; no se lamenta de que hubiesen canonizado a esos santos, sino que su queja se centra en que hubiese quedado fuera el beato Tomás de Villanueva estando el proceso terminado y aprobado con anterioridad.

Tenemos la información directa y personal del padre agustino que le cuenta por carta a un amigo valenciano los hechos y sus sentimientos solo diez días después:

"Nuestro Santo ha quedado afuera por pobre, que viviendo dio todo lo que tenía a pobres y no se reservó nada para sí. Y ahora en esta ocasión tan buena y que el papa le quería canonizar en compañía de los cinco Santos por falta de dinero ha quedado. Considere v. m. que día fue este para mí que no he llorado tanto en mi vida de ver que se canonizaban cinco Santos que yo tenía acabada primero la causa de nuestro Santo primero que ellos y ha quedado sin canonizarse. Quiso Dios aquel día mortificarme del todo (...) El papa ha prometido de canonizarnos al septiembre que viene a nuestro Santo y al beato [Luis] Bertrán, y al beato Pascual Bailón, y al beato Pedro de Alcántara, y a un santo obispo florentino de la orden del Carmen calzado, si me envían con tiempo el dinero y el papa vive se puede esperar seguro la canonización. Yo estoy ya [en]cargado de escribir de esta materia, hagan lo que fueren servidos..."

El 10 de agosto de 1620 -casi dos años y medio antes-, firmaba en Madrid don Francisco de Quevedo la dedicatoria al rey de su vida de Santo Tomás; llamativamente coincidía en la idea de los gastos forzosos de la canonización y el afán del beato por ahorrar:

"Vio Su Santidad las informaciones y determinó su beatificación para consuelo de toda la Iglesia. Y el no canonizarle todo junto, creo que lo remitió Su Santidad con particular providencia, viendo que la devoción no echa menos nada en tan gran santo, y también, la dificultarían los gastos forzosos; y nuestro santo aun muerto ahorra gastos en su persona y en su vida y en su muerte y en su canonización; lo que no hiciera aun en la sepultura, si se tratara de repartir con los pobres".

\footnotetext{
${ }^{8}$ AHN, Diversos-Colecciones, 16,N.1242; Archivo de la Corona de Aragón, Consejo de Aragón (en adelante, ACA, CA, Referente a las canonizaciones de fray Luis Bertrán y don Tomás de Villanueva, leg. 707, $\mathrm{n}^{\circ} 102$.

9 "Epítome de la Historia...", en Obras Completas. Madrid 1979, Obras en prosa, t. II, p. 1283, ed. de F. Buendía. Hay que recordar que esta biografía fue escrita por encargo del P.
} 
A pesar de las consecuencias morales sufridas por la canonización de los grandes santos españoles de 1622, los agustinos de la provincia de la Corona de Aragón siguieron adelante ${ }^{10}$; en esa década consiguieron que el nuevo monarca Felipe IV (1621) se interesase en la causa y la apoyase. Con el dinero sobrante de los gastos de beatificación los agustinos obtuvieron permiso del nuevo papa Urbano VIII (1623) para emplear esos fondos en el proceso de canonización, pero Roma pidió al arzobispo que el encargado rindiese cuentas ${ }^{11}$.

De 1626 y 1628 se conservan cartas del rey a sus embajadores en Roma y al cardenal de Borja mostrando interés por la canonización del beato fray Tomás de Villanueva, por obligación de su padre y por devoción personal suya, y también les indica que los agustinos le dicen que llevan años aguardando y han suplicado por la canonización y le ruegan, con "apretadas instancias", que interceda nuevamente ante el papa con ese objetivo habiendo oído que le quiere canonizar en unión a un carmelita ${ }^{12}$.

\section{FALTA DINERO DEL “ARCA DEL SANTO”}

En el Capítulo intermedio de la Provincia de la Corona de Aragón, celebrado el 15 de diciembre de 1630, el superior fray Marco Antonio Mascarós ${ }^{13}$ presentó

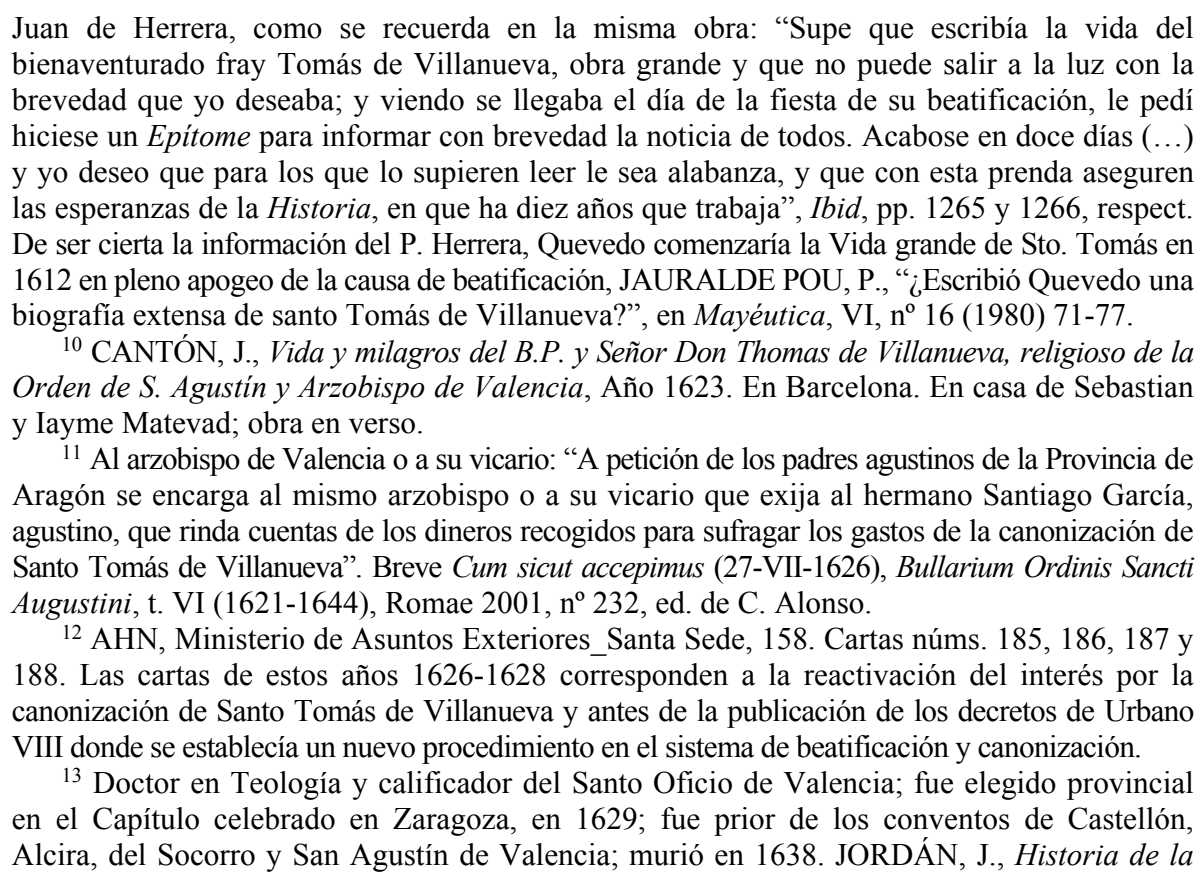


un informe urgente del estado de cuentas del "arca del santo" que se creó en el convento de San Agustín de Valencia para guardar las limosnas entregadas por los devotos y las cuotas fijadas a los conventos así como la documentación relacionada con la canonización del beato fray Tomás de Villanueva. Por actuaciones irregulares de sus administradores, los PP. Sebastián García ${ }^{14}$ y Tomás de Antillón ${ }^{15}$, se cambió a los responsables.

El documento presentado al capítulo es bastante amplio; aquí ofrecemos un resumen con nuestras palabras y fragmentos textuales ${ }^{16}$. El memorial está estructurado en siete puntos:

$\left.1^{\circ}\right)$ La Provincia solo tenía noticia de la existencia de esa hacienda depositada en un arca de cinco llaves "sin que dicha provincia en nombre de provincia hubiese podido ver ni liquidar las cuentas de dicho dinero, ni saber los créditos que hay para emprender su canonización por estar hecho señor de todo el dicho maestro [fray Sebastián] García...”.

$2^{\circ}$ ) Siendo provincial el maestro Tomás de Antillón obtuvo de Urbano VIII un decreto para pedir cuentas al maestro García nombrando al arzobispo para ejecutarlo. El maestro García las presentó pero a la hora de la liquidación se suspendió porque su majestad le mandó salir de la provincia y tiempo después mandó un decreto al provincial actual para que "le recibiese en su provincia y le pusiese en su celda y le dejase leer su cátedra en la Universidad de Valencia sin que el dicho maestro García se metiese en los negocios de la Provincia. Uno de los cuales y el más importante que hay en ella es la administración de dicho

Provincia de la Corono de Aragón de la Sagrada Orden de los Ermitaños de Nuestro Gran Padre San Augustín, t. I, p. 179, n 97; t. II, p. 38, nº 40. Este informe ya lo hemos tratado, en "La glorificación de Santo Tomás de Villanueva en los fondos del Archivo de la Corona de Aragón (I)", Revista Agustiniana (Guadarrama, Madrid), LX/183 (2019) 527-581.

${ }^{14}$ Trabajó bastante como procurador de la causa de canonización de Santo Tomás; catedrático de Filosofía, de Teología Moral y del Maestro de las Sentencias de la Universidad de Valencia; calificador del Santo Oficio y visitador de Librerías de Valencia. Fue elegido provincial en 1623, Rector del Colegio de San Fulgencio, prior de los conventos del Socorro y San Agustín de Valencia; murió en 1633. JORDÁN, J., Historia de la Provincia de la Corono de Aragón..., o.c., t. I, pp. 178-179, n ${ }^{\circ} 95$, pp. 358-364; no dice nada de este asunto del informa que parece grave; SANTIAGO VELA, G. de, Ensayo de una Biblioteca Ibero-Americana de la Orden de San Agustín, Madrid 1917, t. III, pp. 81-84; sigue al P. Jordán y no dice nada de este asunto.

${ }^{15}$ Ingresó y se formó en el convento de Salamanca pero pasó a la provincia de Aragón; elegido provincial apostólico por el papa en 1623, tras anular la elección efectuada en 1625; fue prior de los conventos de Belchite, Huesca y Zaragoza; murió el 1642. JORDÁN, J., Historia de la Provincia de la Corono de Aragón ..., o.c., t. I, p. 179, n 96; SANTIAGO VELA, G. de, Ensayo, o.c., Madrid 1913, t. I, pp. 140-141.

16 Portadilla: "Memorial de los motivos que tuvo la provincia de Aragón para revocar los procuradores que administraban la hacienda del beato Tomás de Villanueva, y para instituir de nuevo la administración que ha instituido para dicha hacienda”, ACA, CA, leg. 766, nº 8/2. 
erario, por el mucho dinero que es menester para los gastos de la canonización del dicho beato".

$3^{\circ}$ ) El breve remitido al señor arzobispo dispone que reparta las tres llaves principales, "con auto de notario público el día que su ilustrísima hizo reconocimiento y vista personal de lo que había en dicha arca del dinero del Santo, de lo cual se tomó también auto público".

$4^{\circ}$ ) Cuando el maestro García se fue clandestinamente a Madrid rechazando ir al convento de Alcoy donde le mandó el arzobispo como comisario apostólico de la provincia entregó las cinco llaves que tenía del arca a Alonso Suñer, amigo suyo y oficial de la Diputación de Valencia, "para que juntando los brazos del Reino sus síndicos sacaren del archivo del convento de San Agustín de Valencia el arca de los papeles y dinero del dicho beato y se la llevasen, y asimismo le dijo que pidiesen los seis mil ducados que su Majestad dio de limosna para la canonización de dicho beato, los cuales estaban (como hoy lo están) depositados en la Tabla de Valencia. Juntó el señor Suñer los síndicos de dichos brazos en el Capítulo de la Seu de Valencia y proveyeron que se hiciese así".

Enterado de ello el P. Marcos Antonio Mascarós, actual provincial, fue a la Seu y les dijo a los diputados que no podían hacer nada respecto al arca y el dinero del beato Tomás; en virtud del breve pontificio el arzobispo tomaba las cuentas del dinero y estaba activando la causa contra el maestro García.

Cuando fue el arzobispo al convento de San Agustín le acompañaban personal del arzobispado y estaban los superiores agustinos; el señor Suñer entregó las llaves y el arzobispo las dio a los tres religiosos que mandaba el decreto pontificio, y las otras dos a los depositarios del convento. "Abriendo todos con sus llaves dicha arca hizo reconocimiento y visura de lo que había en ella, tomando fe y testimonio de todo lo dicho por medio del escribano de su corte que allí estaba".

$5^{\circ}$ ) Siendo provincial el maestro [Bernardo] Navarro se hizo una colecta extraordinaria "con la cual se juntó cantidad tan considerable que excedió (según se entiende) de cuatro mil ducados porque se esforzaron los conventos más de lo que podían (...) Jamás supo la provincia el estado y aumento que había tenido dicho erario por medio de esta colecta (...) Viéndose provincial el que lo es ahora procuró inquirir en el mismo Capítulo de su elección por dónde andaba el dinero que se había collectado (...) que la mayor parte de él estaba en poder [del padre] presentado fray Jerónimo Balle a quien se encomendó el provincial Navarro". Mandó el provincial actual que preparase las cuentas de todo el dinero que tenía a su cargo del erario del beato fray Tomás y pidió a los demás que le informasen de todo lo que supieren. 
$\left.6^{\circ}\right)$ Después de buscar el dinero solo pudo sacar en limpio 771 libras y 2 sueldos que confesó fray Jerónimo Balle que tenía en su poder; murió antes que el provincial llegase a la visita de Barcelona donde debía entregar todo el dinero; más adelante consiguió otras 100 libras que le manifestó tener el maestro fray Benito Daniel Doménech y el Provincial puso el dinero en el depósito del convento de San Agustín de Barcelona.

$7^{\circ}$ ) Los seis mil ducados que el P. Sebastián García siendo provincial había cobrado de la limosna de Felipe III, "se entregaron de parecer y consulta de los maestros y hombres graves de la religión que vivían en Valencia a los Tafallas, gente de mucho crédito en aquella ciudad. Viéndose dicho maestro García sin el provincialato, declarándose su elección por nula, pidió en nombre de procurador del dicho Santo a los Tafallas los seis mil ducados que en nombre de provincial había depositado en su poder". No lo consideraban persona legítima y no los entregaron; promovió pleito en la Real Audiencia de Valencia y la sentencia dictaminó que no se diese el dinero al maestro García, sino que se depositase en la Taula de Valencia (Banco municipal) a suelta de dicho Consejo Real y del provincial de aquella provincia para el efecto de la canonización.

Visto el informe por el definitorio del Capítulo intermedio y comprendiendo los inconvenientes de que solo una persona administrase el depósito del arca determinó unánimemente que se encargase a tres administradores simul et non in solidum, y que fuesen los que el papa había nombrado en el breve para que guardasen las tres llaves, y así se formó el decreto de dicha administración del arca del beato fray Tomás de Villanueva. En fe de lo cual el dicho provincial puso su firma al pie de este memorial. Firmado: fray Marco Antonio Mascarós, provincial de Aragón.

\section{SE REACTIVA EL PROCESO Y SE PIDE LIMOSNA PARA LA CANONIZACIÓN}

Otra importante detención sufrida en el ritmo de la causa de Santo Tomás de Villanueva fue la reforma introducida por Urbano VIII. Con la publicación del breve Caelestis Hierusalem cives (5 julio de 1634), y el posterior Decreta servanda in canonizatione et beatificatione Sanctorum (13 de marzo de 1642) se modificaba profundamente el sistema del proceso de beatificación y canonización ${ }^{17}$, aunque antes habían comenzado algunas modificaciones con los decretos de

17 Un resumen histórico de la parte que nos afecta está en la Introducción de la Constitución Apostólica Divinus perfectionis Magister de Juan Pablo II sobre la nueva legislación relativa a las causas de los santos (25-I-1983): http://w2.vatican.va/content/john-paulii/es/apost_constitutions/documents/hf_jp-ii_apc_25011983_divinus-perfectionis-magister.html 
de la Congregación de la Santa Inquisición romana (13 de marzo y 2 de octubre de 1625$)^{18}$.

Tras una laguna de información volvemos a encontrar documentación en $1645^{19}$. A finales de 1650 pudieron ampliar su captación de donativos en el Nuevo Mundo donde había conventos con gran presencia de religiosos españoles y se recordaba que siendo provincial el beato fray Tomás de Villanueva había impulsado el envío de dos barcadas a Nueva España ${ }^{20}$.

De estos años disponemos de dos epistolarios de diferentes personas sobre la canonización de Santo Tomás de Villanueva, en el los Archivos de la Corona de Aragón ${ }^{21}$ y en el Histórico Nacional de Madrid ${ }^{22}$. En ambos se puede seguir el interés suscitado por la Corona, las instituciones civiles y eclesiásticas de Valencia -especialmente del Consejo de Aragón-, y la propia Orden de San Agustín, superior general y Provincia de la Corona de Aragón; bastantes cartas de Felipe IV a los diversos embajadores en Roma -incluso al propio Alejandro VII-, y de los procuradores agustinos, padres Buenaventura

${ }^{18}$ GOTOR FACELLO, M.A., "La fabrica dei santi: la reforma barberiniana e il modelo tridentino", en Storia d'Italia. Annali (Torino), XVI (2000) 679-727. Santa Rosa de Lima también sufrió las consecuencias del breve urbaniano, HART, S., Edición crítica del Segundo Proceso Apostólico de Santa Rosa de Lima "Rosa a Sancta Maria III Ord. S. Dominici: Supplementa Proc." (1670). Congr. Riti Processus 2208, Archivum Secretum Vaticanum, Lima 2019, pp. 15-17.

${ }^{19}$ El 21-XI-1645 el conde de Monterrey informaba al rey en nombre de la Junta que respaldaban el memorial enviado por el convento de Nuestra Señora del Socorro de Valencia en el que pedían al monarca que escribiese al papa y al embajador interesándose por el tema de la canonización del beato arzobispo, ACA, CA, leg. 1354, nº 23.

${ }^{20}$ Real Cédula concediendo licencia a la Orden de San Agustín de la provincia de Aragón para que, por tiempo de 3 años pueda pedir limosna en todas las Indias como ayuda a la canonización del beato Fray Tomás de Villanueva que fue arzobispo del Reyno de Valencia; forma en que se ha de hacer, guardar y enviar, anualmente, a la Casa de la Contratación de Sevilla. 14-XI-1650. Nota al margen: "Enviose copia de la Secretaría de Nueva España", AGI, INDIFERENTE,429,L.39,F.104V-105V; ÁLVAREZ GUTIÉRREZ, L., "Proyección y devoción a Santo Tomás de Villanueva en América Latina y Filipinas", en ITURBE, A., y TOLLO, R. (Coords.), Santo Tomás de Villanueva. Culto, historia y arte, San Lorenzo del Escorial (Madrid)-Tolentino (Italia), 2013, t. II, pp. 167-191; CERDA FARÍAS, I., "Los agustinos de la Nueva España en tiempos de Santo Tomás de Villanueva, 1533-1555", en CAMPOS y FERNÁNDEZ DE SEVILLA, F.J. (Coord.), La Iglesia y el Mundo Hispánico en tiempos de Santo Tomás de Villanueva (1486-1555), San Lorenzo del Escorial 2018, pp. 411-412.

${ }^{21}$ CAMPOS Y FERNÁNDEZ DE SEVILLA, F.J., "La glorificación de Santo Tomás de Villanueva en los fondos del Archivo de la Corona de Aragón (I)”, en Revista Agustiniana (Guadarrama, Madrid) LX/183 (2019) 527-581.

22 IDEM, "La Corona española y Santo Tomás de Villanueva en la correspondencia con la Santa Sede durante el siglo XVII", en Cuadernos de Estudios Manchegos (Ciudad Real), $n^{\circ} 44$ (2019) 127-142. 
Fuster $^{23}$ y Andrés Aznar ${ }^{24}$, que estuvieron al tanto de lo que sucedía en la Sagrada Congregación de Ritos y con gran habilidad supieron no solamente informar al monarca detalladamente sino sugerir ciertas actuaciones que apoyaba el señor don Gaspar de Sobremonte, del Consejo de Castilla, de Italia, y lugarteniente de la Cámara en la Sumaria de Nápoles ${ }^{25}$.

En 1652 el P. Buenaventura Fuster publicó un memorial donde cuenta la situación en que se encontraba la canonización aprovechando los progresos obtenidos en Roma en la marcha del proceso y el impulso dado por el rey y las instituciones del Reino de Valencia ${ }^{26}$.

Esta explicación del P. Buenaventura es para justificar la necesidad que hay de obtener dinero; con mayor motivo siendo el beato fray Tomás pobre como lo fue siendo arzobispo ya que las rentas del arzobispado eran para los pobres que eran sus dueños.

“Oy pues, está el santo Arçobispo pidiendo limosna para su Canonización: y si todo él, y su hazienda fue para los pobres, bien merece, que quando llega a pedir para su Canonización, le den limosna todos los amigos de los pobres. Y es cierto, que siendo tan agradecido, recibiendo dará con ventajas el retorno"27.

Uno de los testimonios más conocidos en este sentido y que se supo tanto en Valencia como en la corte del emperador fue su reacción cuando los ibicencos pidieron ayuda a Carlos V para fortificarse ante el peligro en que se hallaban

23 JORDÁN, J., Historia de la Provincia de la Corono de Aragón..., o.c., t. I, pp. 490491, no 17; t. II, p. 40, no 51; SANTIAGO VELA, G. de, Ensayo ..., o.c., t. II, pp. 688-689.

${ }^{24}$ Profesó en el convento de Zaragoza el 1632; trasladado al Perú encauzó la provincia agustina de Ntra. Sra. de Gracia y asistente por ella participó en el Capítulo general de 1655 donde fue nombrado asistente general de España e Indias; calificador de la Inquisición romana y consultor del santo Oficio. En 1662 Felipe IV le propuso para obispo de Alguer (Cerdeña), donde también desempeñó el cargo de diputado y virrey (1669); pasó como titular a diócesis de Jaca (1672), y a Teruel en 1674. Falleció en 1689; JORDÁN, J., Historia de la Provincia de la Corono de Aragón ..., o.c., t. III, p. 177, nº 4; LATASSA Y ORTÍN, F. de, Biblioteca Nueva de los Escritores Aragoneses..., Pamplona 1799, n ${ }^{\circ}$ 460, pp. 582-584; LAZCANO, R., Episcopologio Agustiniano, Guadarrama (Madrid) 2014, t. I, pp. 440-445; http://www.enciclopedia-aragonesa.com/

voz.asp?voz_id=1697\&tipo_busqueda=1\&nombre=fray\%20andr\%E9s\%20aznar\&categoria_i $\mathrm{d}=\&$ subcategoria $\mathrm{id}=\&$ conImagenes $=$.

${ }^{25}$ BARRIENTŌOS GRANDÓN, J., "Sobremonte y Villalobos, Gaspar de”, en Diccionario Histórico Español, t. XLVI, p. 981.

${ }^{26}$ ANÓNIMO, Memorial en que se pide limosna para la canonización del B. Fr. Thomas de Villanueva, Arzobispo de Valencia, s.l., s.a. Ej. en la Biblioteca Nacional, V.E. 159/3. De fray B. Fuster de Ribera, 1652.

${ }^{27} \mathrm{Ibid}$, p. 7v (ó 158v). 
los pobres y los habitantes de la isla, vecinos a Valencia, de las sistemáticas campañas de saqueos y aprehensión de rehenes por parte de los turcos en las costas del Mediterráneo occidental ya conocidas de otras veces. El emperador escucho la petición de los naturales de Ibiza y les mandó a su amigo el arzobispo de Valencia.

La cuestión era delicada porque se debatía entre los pobres y la obediencia a su señor; fray Tomás recurrió a la justicia como norma de bien moral. Reunió a los pobres de la ciudad como propietarios de las rentas y les planteó el problema, sus obligaciones de conciencia y la respuesta que había dado como administrador, pero necesitaba su consentimiento ${ }^{28}$. Acordaron darle al emperador los 20.000 ducados que pedía con estas condiciones: 10.000 ducs. se le entregaban para socorrer a los pobres de la isla, y de los otros 10.000 que se prestaban a su Majestad necesitaba aceptación de la deuda y garantías de la forma del pago señalando el calendario y forma de la devolución ${ }^{29}$. Poco tiempo después de llegar a Valencia, en otro momento de apuro ya había prestado al emperador 6000 ducs., también con obligación de devolverle pare lo antes posible y el resto en la feria de Medina del Campo ${ }^{30}$.

El 9 de febrero de 1652 desde Roma escribe el embajador de España, cardenal Tribulcio, comunicando a Felipe IV la gran noticia de que la Sagrada Congregación de Ritos con la presencia de Inocencio X habían aprobado las causas de los beatos fray Tomás de Villanueva y fray Félix Cantalicio, de cincuenta candidatos que se habían presentado, y podría estar dispuesto para la canonización en unos seis meses si la solicitasen los interesados ${ }^{31}$. El 3 de

${ }^{28}$ Y así lo ratifica el P. Fuster: "Murió tan pobre, y con tales ansias, que antes de dar el alma a su Señor, y pasar las cuentas del recibo de sus talentos, y rentas que administró, tomó cartas de pago de los pobres, cuyas eran las rentas del Arçobispado...", Ibid, p. 3 (ó 154).

${ }^{29}$ SALÓN, M., Libro de la Vida y Milagros de Santo Tomás de Villanueva..., o.c., pp. 171-172. Y así explica el final: "Cobró los siete mil viviendo; los tres mil se han cobrado después de su muerte, y empleado en las obras pías que mandó", p. 172. Tan conocido fue el hecho que cuando en octubre de 1738 se conmemoró el V Centenario de la Conquista de Valencia en las fiestas organizadas el altar efímero del convento de Socorro se inspiró en este suceso, ORTÍ, J.V., Fiestas Centenarias con que... Valencia... celebró... la quinta centuria de su cristiana conquista, Valencia 1740, pp. 158-160, reproduciendo la imagen del altar. Pedro Colombo recoge el hecho pero lo pone en una petición del emperador para levantar una fortaleza en África, VILLEGAS, A. de, Flos Sanctorum, Madrid 1675, pp. 693-697, ed. de P. Colombo, p. 696.

30 "Carta a don Fernando de Aragón, duque de Calabria y virrey de Valencia, anunciándole que contribuirá con 6000 ducados para el servicio del emperador". Valencia, 25-X-1546. Texto, en Cartas y Testamento de Santo Tomás de Villanueva, ed. de F. J. Campos, Madrid 2006, ${ }^{\circ}$ 16, pp. 105-110, ed. de F.J. Campos.

31 Archivo General de Simancas, Consejo de Aragón, leg. 1244. Texto, en Colección de Documentos Inéditos para la Historia de España (CODOIN), Madrid, Imprenta De La Viuda De Calero, 1844, t. V, pp. 126-127; ACA, CA, leg. 731, nº 55/1. Documenti per la canonizzazione di 
junio de ese año el P. fray Felipe Visconti, superior general de los agustinos, comunicaba al rey la misma noticia ${ }^{32}$.

Inmediatamente el papa nombró comisarios apostólicos al arzobispo de Valencia, fray Pedro de Urbina, y a los obispos de Tortosa - ¿también al de Segorbe?-, para efectuar las diligencias relativas a la Remisoriales -repetición del proceso de información- como último paso para la canonización, por cuyo tema ya se había interesado el rey en cartas a su embajador ${ }^{33}$. El 7 de junio de 1652 Felipe IV escribía a los prelados urgiéndoles que dispusiesen la documentación solicitada por Roma:

"Y porque esta es materia que no requiere mucho tiempo, y yo deseo ver colocado en el número de los Santos al B. Fr. Tomás de Villanueva, Arçobispo que fue de essa santa Iglesia, he querido encargaros (como lo hago con mucha instancia) la breuedad, haziendo lo mismo con el Obispo de Torosa, a quien escribo, y doy licencia para que vaya a essa Ciudad, y execute por su parte la comisión que tiene de su Santidad también para el mismo efecto" 34 .

Por muerte del obispo de Segorbe y la ausencia del de Tortosa -electo de Puzol, Nápoles-, se nombró nuevos comisarios a los prelados de Orihuela y Maronea, cuyos breves y texto de las Remisoriales llegaron a Valencia el 7 de mayo de 1653 siendo recibidos con gran alegría y llevados solemnemente a la Iglesia metropolitana donde se entregaron los despachos al señor arzobispo fray Pedro de Urbina, a Don Luis Crespi de Valdaura, obispo de

del beato Tommaso di Villanova, vescovo di Valentina, inviati alla 'Sacra Congregatio Rituum' nella persona del cardinal Pallotto. [Valentina, canonizationis B. Thomae de Villanova (1r)], BAR, ms. 192, cc. 1r-144v.

${ }^{32}$ Memorial en que se pide limosna ..., o.c., p. 5 (ó 156).

33 AHN, Ministerio de Asuntos Exteriores Santa Sede, 158. Cartas núms. 189 y 190, Madrid, 30-VI-1650; cfr. nota 4. Se conoce con el nombre de "Letras Remisoriales" los procesos de canonización iniciados por la Santa Sede, con autorización expresa del pontífice, que encarga a los obispos/arzobispos de la diócesis relacionadas con el/la venerable nominado/da. La Sagrada Congregación de Ritos es la que establecía el sistema completo de actuación, tanto respecto al contenido -el mismo interrogatorio para cada lugar-, como las personas que lo debían realizar y el procedimiento que se debía seguir en las deposiciones de los testigos -examinando las cualidades y relación de los mismos en esa causa-, y garantía de los traslados hechos. Las Órdenes religiosas eran las que iniciaban las causas, nombraban procurador, postuladores y recolectores, que no eran los miembros del tribunal que luego realizaban las actuaciones. Cada uno de los procesos desarrollados en cada una de las diócesis, si había más de una, firmados y sellados bajo juramento de ser verdad lo que se adjunta, se enviaban a Roma para estudio por los miembros del tribunal del proceso apostólico. Procesos de beatificación y canonización, en http://censoarchivos.mcu.es/CensoGuia/fondoDetail.htm?archivoId=24940\& id $=1703670$ \&eventDescendiente $=$ descendienteDetail.

${ }^{34}$ Memorial en que se pide limosna ..., o.c., p. 5v (ó 156v). 
Orihuela, y a don Jacinto Minuarte, obispo de Maronea, comisarios apostólicos. En señal de regocijo se proclamaron tres días de fiestas -8/10 de mayo-, que organizaron los agustinos, el gobierno de la ciudad y el cabildo eclesiástico en el marco de una celebración barroca, con pregón general, toque de campanas, iluminaciones, adornos de edificios, fuegos artificiales, música, sermones y oficios religiosos, etc. ${ }^{35}$.

El día 13 fueron los obispos de la comisión al convento del Socorro a reconocer la capilla funeraria y el sepulcro del beato viendo la cantidad de exvotos y ofrendas de plata donados por los devotos en agradecimiento por los beneficios recibidos de Dios nuestro Señor por intercesión del bendito fray Tomás, cuyos milagros y devoción de los fieles fueron analizados por los prelados $^{36}$.

"Y en este exercicio se ocupan todos los días, deseando cumplir con breuedad su comisión, y remitir a Roma el despacho, que será breuemente, a la Congregación de Ritos, para que su Santidad consuele, y condescienda a las peticiones que el Rey nuestro señor, Prelados, Cabildos, Ciudades, y la Religión de san Agustín le están haciendo, para lograr el fin tan deseado desta Canonización; pues para ella con tanta liberalidad, todos han acudido, y acuden con sus limosnas" ${ }^{37}$.

Todo ese preámbulo histórico que refiere el P. Fuster es para indicar que la Orden agustina había nombrado al vicario provincial del Reino de Valencia, fray Tomás Figuerola ${ }^{38}$ y a los administradores de los fondos para la canonización con facultad apostólica para pedir limosnas y ayuda de costa para los gastos que se estimaban en una cantidad próxima a los 30.000 ducs., además de lo ya recaudado, que debería estar depositado en Roma a comienzos de noviembre de

${ }^{35}$ Relación de la entrega que se hizo en la Ciudad de Valencia a los Illustrissimos Señores Arzobispo de aquella Metropolitana Iglesia, y Obispos de Origuela, y Maronea, Iuezes Comissarios Apostólicos de los Breues, y Remisoriales, para el vltimo examen a la Canonización del Beato Arçobispo Fr. Thomas de Villanueva, de la Orden de San Agustín. Remitida a el P. Fr. Buenaventura Fuster der Ribera, Difinidor y Procurador General de la dicha Canonización a esta Corte. Real Academia de la Historia, Colección Salazar y Castro (En adelante, RAH, Col. SyC), U-11, fols. 317bis-318.

${ }^{36} \mathrm{Y}$ así informa fray Buenaventura Fuster al rey que se está efectuando en carta del 1-VII1653, ACA, CA, leg. 899, n 69/1. ORTÍ, J.V., Vida, Virtudes, Milagros y Festivos Cultos de Santo Tomás de Villanueva... Valencia 1731, pp. 345-347.

${ }^{37} \mathrm{Ibid}$, fol. 318.

${ }^{38}$ Doctor en Teología y catedrático en la Universidad de Valencia y examinador sinodal del arzobispado; rector del Colegio de San Fulgencio, dos veces prior del convento del Socorro de Valencia y otras dos superior provincial. Murió en 1673. JORDÁN, J., Historia de la Provincia de la Corono de Aragón, o.c., t. I, p. 181, $\mathrm{n}^{\circ} 103$, y p. 506, n 34; t. II, p. 39, $\mathrm{n}^{\mathrm{o}}$ 48; SANTIAGO VELA, G. de, Ensayo, o.c., Madrid 1915, t. II, pp. 497-498. 
este mismo año 1652. Y finaliza el Memorial exhortando a la piedad y liberalidad de todos ya que el santo arzobispo se presenta pidiendo una limosna, especialmente a algunos Reales Consejos del gobierno polisinodial de la monarquía de los Habsburgo ${ }^{39}$.

El 5 de junio de 1653 fray Buenaventura Fuster escribe una amplia carta al padre general, fray Felipe Visconti (1649-1655); la carta está impresa lo que significa que fue un documento enviado a otros destinatarios. El texto es un ejemplo de autobombo, en este caso justo y merecido porque fue un siervo fiel y eficaz, y figura clave en la canonización de Santo Tomás de Villanueva como demuestra en lo que refiere, y no lo cuenta todo ${ }^{40}$.

Hacemos un resumen de los aspectos más importantes de la carta como mejor desarrollo del amplísimo y sugerente contenido:

- Reconoce la eficaz intervención que ha tenido en relación con el proceso ante Inocencio X y la Sagrada Congregación de Ritos como le ha agradecido el rey de España en carta personal de 8 de agosto de 1650.

- Recuerda que consiguió de Felipe III una limosna de 6000 ducs. en plata doble para ayuda de los gastos que se hizo efectiva en el reinado de Felipe IV que lo necesitase para la que depositó en la Tabla de Valencia con garantía de recuperarlo en el momento canonización.

- Siendo procurador general de la causa el P. Belda, en el pontificado de Gregorio XV (1621-1623), se pidió a los agustinos que se necesitaba dinero para seguir adelante, y envió a Roma, juntamente con el padre Sebastián García que era el otro procurador, 21.000 ducs. de oro en créditos que libraron los banqueros valencianos Muraltis y Loçoyas, correspondientes a las estampas hechas.

- Por la muerte del papa ( 8 de julio de 1623) se suspendió el proceso y se recuperó el dinero y se devolvió a los dueños.

- El P. Sebastián García entregó a Felipe IV una reliquia insigne en un cofre de plata correspondiente a un omóplato del beato fray Tomás que se depositó en el Real Monasterio de la Encarnación de la corte y por medio de ella se

\footnotetext{
${ }^{39}$ Memorial en que se pide limosna ..., o.c., p. 7v (ó 158v).

${ }^{40}$ Carta que escribe a Roma el Procurador General Fray Buenaventura Fuster de Ribera, de la Prouincia de los Reynos Corona de Aragón, de la Orden de S. Agustín, al Reuerendissimo Padre Maestro Fray Felipe Visconti de Milán, Prior General de su Orden, en que da cuenta del Estado de lo que ha obrado en orden a la Canonización del Beato Fray Thomas de Villanueva, Arçobispo de Valencia. Texto, en ACA, CA, leg. 899, nº 69/5.
} 
experimentaron muchas gracias especialmente la curación de la madre sor Ana Margarita de San José de Austria ${ }^{41}$.

- Fue designado de nuevo procurador para pasar a las Indias, y obtenido licencia, a pedir limosna en las siete provincias agustinianas; por una grave enfermedad tuvo que renunciar al viaje ${ }^{42}$.

- En el capítulo provincial celebrado en Castellón en 1648 fue nombrado de nuevo procurador general y programó a una campaña pidiendo a las instituciones valencianas cartas al rey en las que pidiesen que intercediese ante su santidad por la canonización de beato fray Tomás; también al embajador duque del Infantado y su sucesor el cardenal Tribulcio. Se envió a Roma con las cartas y dinero para los gastos a un religioso ${ }^{43}$.

- En 1650 solicitó nueva licencia del monarca para que en las provincias occidentales se hiciese cuestación de limosnas obteniendo doscientas cédulas reales, firmadas de su real mano y por una duración de tres años. Se enviaron en 1651 a todas las autoridades de Indias, civiles y eclesiásticas, regulares y seculares, con el aval del padre general, provincial y administradores de las rentas del beato.

- Para difundir el conocimiento de la vida y milagros del santo imprimió a su costa en 1651 -según la cubierta, y 1652 en la portada-, una nueva edición de la Vida del P. Salón, añadiendo un suplemento donde se explicaba la situación en que se encontraba el proceso en Roma ${ }^{44}$.

${ }^{41}$ En el verano de 1652 el P. Fuster envió unos memoriales solicitando al rey una limosna. Tenemos el dictamen del Consejo a la consulta del monarca del 28-VII donde le recuerda el milagro que había hecho en la curación de la Infanta Sor Ana Margarita de San José; la Cámara respondió el 3-VIII poniendo reparos por la estrechez del momento, AHN, Consejos (Consultas de gracia), leg. 4433, exp. 56; la infanta fue hija natural de Felipe IV y profesó en 1650 de cuya ceremonia se conserva en el convento un lienzo de Antonio Pereda. "Relicario de Santo Tomás de Villanueva", en ITURBE, A., y TOLLO, R. (Coords.), Santo Tomás de Villanueva. Culto, historia y arte, Tolentino-San Lorenzo del Escorial 2013, t. II, pp. 30-31, lám. 38; SÁNCHEZ HERNÁNDEZ, L., "Servidoras de dios, leales al papa. las monjas de los monasterios reales", en Librosdelacorte.es, Monográfico 1, año 6 (2014). Poco antes de la canonización, el 5-VI-1658, desde Roma escribía don Gaspar de Sobremonte al rey y le sugería que, además de la carta personal que le escriba a su santidad, "también convendrá que venga otra de la señora infanta", ACA, CA, leg. 740. $n^{\circ} 22 / 1$, y leg. 740, no 22/3. En el listado del Apéndice consta que "dio de limosna dos Blandones de plata para el Sepulcro del santo Arzobispo, de peso de quinientos ducados".

${ }^{42}$ Las provincias de la Orden en las Colinas eran: México (2), Perú, Ecuador, ColombiaVenezuela, Chile y Filipinas (con la extensión de China y Japón), GUTIÉRREZ, D., Los agustinos desde el protestantismo hasta la restauración católica, 1518-1648, Roma 1971, pp. 85-89 y 230-258.

${ }^{43}$ ACA, CA, leg. 899, no 69/1 y 4.

${ }^{44}$ Vida y Milagros del Ilvstrmo, y Revermo. Señore el B. P. D. F. Tomas de Villanveva, Arçobispo de Valencia, del Orden de San Agvustin... La dio a la Estampa en esta segunda 
- No se olvidó de pedir limosna en los pueblos e instituciones de la Corona de Castilla donde obtuvo una respuesta superabundante como se puede ver en una hoja impresa en Madrid, ascendiendo todo a más de 30.000 ducs. de vellón.

- Hizo una nueva campaña de cartas para enviar a Roma pidiendo y suplicando a su santidad les consuele concluyendo con brevedad la deseada canonización.

- También obtuvo licencia real por medio del Real Consejo de las Órdenes Militares, para pedir limosna en el territorio de su jurisdicción especialmente la comarca del Campo de Montiel y en el distrito de Villanueva de los Infantes, la patria de fray Tomás de Villanueva; para esta cuestación envió como colector con poderes desde la corte a su compañero el P. fray Francisco de Escales.

- Confiesa al padre general que no regateará esfuerzos para conseguir limosnas y animado a todos para que socorran al santo imprimiendo papeles, escribiendo memoriales y estampas con su imagen y extender su devoción.

- Le recuerda los cargos que ha tenido en su provincia: seis veces prior, definidor y secretario, pero sobre todo lo que más se honra es de ser ecónomo y colector general de las limosnas del santo arzobispo.

- No olvida mencionar el tema al que se aludió en algunas ocasiones que la canonización Santo Tomás traería "por su intercesión a España tantos triumphos, y vitorias, y estas en orden a la general paz que se desea".

- Se muestra contento con que el papa haya enviado las Remisoriales a Valencia y de que los obispos de la comisión apostólica "tratan con toda priessa el concluir la dicha información, que es la vltima función para la Canonizaciones de santos, en conformidad del decreto vltimo de Vrbano VIII ${ }^{45}$.

- Antes de finalizar deja explícita su entrega: "no leuantaré la mano hasta conseguir el efecto de la Canonización. Y así lo he prometido cumplir, confiando que Dios Nuestro Señor, no me atajara la vida, sin que primero para consuelo de todos y mío consiga este aplauso y triunpho general de entrambas Iglesias, Militante, y Triumphante" ${ }^{\$ 6}$.

impression, con vn tratado del estado de la Canonizacion, y causa del dicho Beato Arçobispo... En Valencia. En la casa de los herederos de Chrisostomo Garriz... Año de 1652, pp. 551-566.

${ }^{45}$ Breve Caelestis Hierusalem cives, de 5-VII-1634, y el posterior Decreta servanda in canonizatione et beatificatione Sanctorum, de 13-III-1642. Antes habían comenzado ya las modificaciones de los procesos con los decretos de la Congregación de la Santa Inquisición romana, de 13-III y 2-X-1625, incorporados al breve urbaniano citado, sobre el non cultu. En estos documentos quedó estructurado el sistema que se habría que seguir en el proceso de beatificación y canonización.

${ }^{46} \mathrm{Ibid}$, casi al final. VINCENT-CASSY, C., "Llevando a Santo Tomás de Villanueva (1486-1555) a los altares. Del proceso al modelo de santidad", en Chronica Nova (Universidad de Granada), 43 


\section{INTERVIENEN EL REY Y LA NUNCIATURA}

El 1 de julio de 1653 fray Buenaventura Fuster escribía a Felipe IV una carta donde le informaba que la comisión apostólica estaba trabajando en la respuesta a las Remisoriales y le sugería que interviniese para controlar el dinero de las limosnas y los gastos que se deberían efectuar en la canonización así como instar al provincial agustino a que se recuperase el dinero y que se pidiesen cuentas a los administradores y justificasen los gastos realizados. Sorprende que se dirija al monarca sobre unos aspectos tan concretos:

"Y por cuanto, Señor, vuestra majestad y Reales Consejos, prelados e iglesias y otras comunidades y personas devotas han dado gruesas limosnas para esta canonización y desea que con toda legalidad y fidelidad se distribuyan en dicho efecto convendrá que vuestra majestad interponga su real autoridad no consintiendo que los gastos que se ofrecerán en las diligencias de esta canonización pasen por mano inconfidente, sino por aquella que vuestra majestad nombrare para ir a Roma, que sea celosa de los bienes y limosnas del santo y de su causa.

Y asimismo se escriba al provincial y definitorio del Capítulo próximo celebrando en Zaragoza para que precisa y perentoriamente sin dilación alguna traten de recoger el dinero e intereses procedidos de los seis mil ducados que vuestra majestad dio de limosna, y la demás cantidades que se dieron para este efecto años ha. $Y$ aquellas efectivamente se restituyan en especie de moneda corriente como lo estaba y no en otra. Y que se vuelvan al arca de las cinco llaves de la administración del santo, y que de allí no se saque ninguna, menos que para el dicho efecto de la canonización. Y asimismo que tomen cuenta a los administradores y a los demás que han hecho los gastos en Roma hasta ahora y que se justifique aquellos cesante cualesquiera otras órdenes en contrario. Y que de todo hagan relación y den cuenta a vuestra majestad, y en ello recibiremos merced, etc." ${ }^{\circ 7}$.

El 31 de ese mes el rey se dirige al Capítulo provincial de los agustinos de la Provincia de la Corona de Aragón; en relación con la carta anterior sorprende más que Felipe IV aceptase las indicaciones del padre Fuster y pidiese a los agustinos lo que le había sugerido, así como también que mostrase tanto interés personal en los aspectos de la gestión de la canonización y la prontitud en escribir:

(2017) 114-118; CAMPOS Y FERNÁNDEZ DE SEVILLA, F.J., "El agustino fray Juan Belda procurador de la Beatificación...”, o.c., p. 492.

${ }^{47}$ ACA, CA, leg. 899, nº 69/1. 
"Y con esta ocasión por lo mucho que deseo el efecto de esta canonización, como por la parte que tengo en ella con las limosnas tan considerables que el rey, mi señor y padre, que santa gloria haya y yo hemos mandado dar, y es mi voluntad que se conocerán? en este efecto con toda fidelidad y legalidad, ha parecido encargaros que nombréis persona para ello de la satisfacción, autoridad y celo que conviene por cuya mano y no otra corran en Roma los gastos que se hicieren en esta causa, y tomaréis cuenta de los que hasta ahora se hubieren hecho y haréis que los justifiquen no obstante cualesquier órdenes pues esta es tan justa y conveniente que también la daréis para que estén de manifiesto los seis mil ducados que mandó dar el rey mi señor y padre y los corridos de ellos, y para que si se hubieren divertido a otros efectos se recojan con prontitud y se tengan en moneda corriente y no en otra calidad ni especie poniéndolos en el arca de esta administración que tenéis en el convento de San Agustín de Valencia sin que de allí se puedan sacar para otro efecto que el referido, en que me serviréis como lo espero del celo con que acudís a la veneración de este santo y a todo lo que redunda en autoridad y beneficio de esa sagrada religión, y me daréis cuenta de lo que se ejecutare" ${ }^{, 48}$.

Al año siguiente -abril de 1654- se celebró Capítulo provincial en el convento de Épila (Zaragoza), bajo la presidencia del P. Andrés Aznar, vicario general de la Orden de San Agustín, y la fuerza del mandato del de rey pesó sobre la reunión de los agustinos hasta convertirse el tema de las cuentas de la canonización en asunto prioritario como vemos en los decretos aprobados:

Primeramente el presidente comunica que ha recibido "una carta de su majestad (que Dios guarde) en que manda al definitorio se recobre y recoja toda la hacienda que tiene nuestro Padre el Beato Fr. Tomás de Villanueva para que con efecto se trate de su canonización en todos los reinos de esta Provincia y que se tomen rigurosas cuentas a todos los que han administrado y tenido procura de nuestro Padre Santo Tomás por haber sido las mayores limosnas de la casa Real, y haber entendido que entra mucha parte de hacienda esparcida. Por tanto resolvieron los reverendos padres del definitorio le remitiese esta causa a nuestro muy reverendo padre presidente para que, o por sí mismo, o por las personas que nombrare, tome cuentas rigurosas a todos cuantos han tenido hacienda del santo, y con efecto mande cobrar todo lo que se le debe, y ponerlo en el arca de su depósito que para esto tiene la Provincia" ${ }^{49}$.

\footnotetext{
${ }^{48}$ ACA, CA, leg. 899, nº 69/4.

${ }^{49} \mathrm{AHN}$, Libro de actas de capitulos de la orden agustiniana en la provincia de Aragón, CODICES,L.569, ff 1-1v.
} 
Urgía poner las cosas en claro ya que los trámites para la canonización estaban en la fase final y avanzaban a buen ritmo. El 15 de abril de 1656 el P. Aznar escribía al rey comunicándole que el 28 del mes anterior la Sagrada Congregación de Ritos había finalizado la causa del proceso del beato fray Tomás de Villanueva en la que "se declaró por todos los votos ser buena la valididad del proceso y relevancia de los milagros, y su santidad aprobó uno y otro con especial gozo y grande consuelo de los fieles". Reconocía la buena actuación que habían tenido el embajador duque de Terranova y el procurador fray Buenaventura Fuster, y le anunciaba que el próximo día 19 partía de Roma a dar cuenta a su majestad de todo lo sucedido ${ }^{50}$.

Por el estado de la situación los superiores agustinos trataron de aclarar los asuntos del dinero del arca de Santo Tomás descubriendo fugas que no eran fácil localizar y recuperar. De 1658 tenemos dos cartas -una sin fecha-, relacionadas con el tema ${ }^{51}$. Una es una relación de cuentas del dinero del arca de Santo Tomás de Villanueva; se trata de un texto anónimo y sin fecha. El texto no es de un agustino pero tuvo que ser de alguien estrechamente ligado a ellos para tener acceso a esa información de bastantes años puesto que aparecen citadas partidas desde 1630 hasta 1656; de todas formas es anterior, y hasta muy próxima a la canonización que es cuando se agravó la marcha del proceso por falta de dinero en Roma $^{52}$. Respecto al destinatario, por del tratamiento de V.E. que le da el autor, podría estar dirigido al vicecanciller del Consejo de Aragón que encabeza el listado de los miembros en varios documentos de esta correspondencia, y que al final le califica de "gran príncipe y devoto del santo".

"Ilustrísimo y excelentísimo señor. Habiendo tenido noticia un devoto de Santo Tomás de Villanueva de que puede ser se deje de canonizar dicho santo por falta de dinero doy noticia a vuestra excelencia de dónde se puedan sacar algunas cantidades de importancia, y para seguro de esta verdad mande vuestra excelencia a los Padres Agustinos administradores del arca y pecunias de dicho santo den y entreguen a vuestra excelencia el libro de recibo y gasto que está custodido en dicha arca del Santo del cual se podrá sacar ser verdad las noticias que aquí se advierten a vuestra excelencia ...."53.

${ }^{50}$ ACA, CA, leg. 903, $\mathrm{n}^{\mathrm{0}} 77 / 1$.

${ }^{51}$ ACA, CA, leg. $745, n^{\circ} 1 / 2$ y 3 . Por error de catalogación este documento se ha divido en dos partes.

${ }^{52}$ Teniendo en cuenta que habla sólo de "algunas cantidades de importancia", arroja el recuento: 7601 libras, 11 sueldos, 6 diners. 1 libra $=20$ sueldos $=240$ diners.

53 ACA, CA, leg. 745, $n^{\circ} 1 / 2$ y 3 . Y de esa misma fecha tenemos la carta a Felipe IV donde el procurador agustino le recuerda que de unos censos de Santo Tomás puestos en la Tabla de la Ciudad (Valencia) se le debe 1292 libras; se pusieron con la condición de 
A continuación sigue una carta, posiblemente del secretario del Consejo Real de Aragón, donde se habla de informar al señor Nuncio para que se cree una comisión que investigue el paradero del dinero y lo recupere, poniendo al frente al obispo de Orihuela, que había sido uno de los tres prelados elegidos por el papa en 1653 para formar parte de la comisión de preparar las Remisoriales; el prelado don Luis Crespi y Borja había sido trasladado recientemente a la diócesis de Plasencia el 2 de septiembre de 1658 y fue sustituido por el nuevo prelado de la diócesis oriolana.

La portadilla reza como "Deudas que tocan al arca y canonización del beato Tomás de Villanueva arzobispo de Valencia. En Madrid, a 8 de octubre 1658 .

Dese copia de este papel al Nuncio llevándole yo recado en nombre del Comisario para que tenga por bien de mandar despachar una comisión particular al P. fray Pedro Alginat de Médicis, de la Orden del Carmen calzado, obispo de Orihuela, en el Reino de Valencia, para que averigüe y cobre estas cantidades que se deben al arca y canonización del beato arzobispo Don Tomás de Villanueva, y haga en orden a ello todas las diligencias necesarias [firma y rúbrica].

[Después de la firma hay una apostilla:] Habiendo dado este recado al Nuncio respondió que se despacharía esta comisión".

Y de muy poco después de la canonización disponemos de dos documentos. Uno sin fecha pero muy probablemente 1658, es un memorial de fray Andrés Ferrer, procurador general de la causa de la canonización; el otro es una consulta del 9 de diciembre de 1658 al Consejo de Aragón en los que aparece una limosna del rey de 1000 ducs. para cobrar de unas cargas de bacalao que llegarán al puerto der Cartagena; como por ese puerto había poco movimiento fray Andrés solicita que se pase la concesión al puerto de Alicante ${ }^{54}$.

Otros 1000 ducados había entregado el rey en agosto de 1652; el 9 de agosto de ese año el rey enviaba al Consejo un decreto con un memorial del P. Fuster en el que le adjuntaba una reliquia del santo; la respuesta del Consejo fue más tolerante de la que había dado pocos días antes: "Parece al Consejo será muy digno de la piedad de V.M. que se ayude a esta canonización con una limosna de hasta mil ducados por una vez en expedientes que no salgan de la Real hacienda, V.M. mandará lo que fuese servido. En Madrid, a 12 de agosto de 1652",55.

recuperarlos cuando fuese necesario para los gastos de la canonización, y ahora hace faltan en Roma, ACA, CA, leg. 906, nº $38 / 12$.

${ }^{54}$ ACA, CA, legs. 663, no 60/8 y 9.

${ }^{55}$ ACA, CA, leg. 638, no 32 ; CODOIN, t. V, pp. 128-129 y 130. 


\section{ARREGLO FINAL}

La más inmediata información de la canonización y las últimas acciones oficiales efectuadas ante su santidad la tuvo el rey por carta de don Gaspar de Sobremonte, de su Consejo, en carta desde Roma el día 4 de noviembre de $1658^{56}$.

Aunque la canonización del beato arzobispo de Valencia tuvo lugar el 1 de noviembre de 1658, no finalizó ahí el asunto del dinero y de las cuentas. De pocos meses después tenemos tres documentos muy seguidos donde la Curia General de la Orden de San Agustín toma medidas para tratar de terminar con el tema y hacerlo con claridad.

El protagonista fue el P. fray Andrés Aznar, asistente general de la Orden de España y las Indias, y primer religioso de la Provincia de la Corona de Aragón que accedía a ese alto puesto ${ }^{57}$. Desde su cargo impulsó definitivamente el tramo final de la canonización de Santo Tomás de Villanueva y lo recogió por escrito ${ }^{58}$. El 21 de noviembre de 1658 comunicaba al rey la canonización, "la cual se celebró día de todos los Santos con la mayor majestad, lucimiento y aplauso que hasta hoy se haya celebrado canonización alguna"; en ella le recordaba las cartas de enero y junio donde le informaba de las dificultades económicas para seguir adelante con el proceso y avisándole que la canonización podía quedar suspendida, y los trabajos para conseguir el dinero -que salieron de un préstamo del convento de San Agustín de Roma como veremos más adelante-, y "que tuviese efecto negocio que tanto importaba al consuelo de los fieles y al crédito de los reinos de vuestra majestad" ${ }^{\prime \prime}$.

Los tres documentos que decimos, son:

- Roma, 18 de enero de 1659. Bula a fray Andrés Aznar, religioso profeso de la Orden de Ermitaños de San Agustín, asistente de las provincias de España y maestro en teología. Se le ordena que inspeccione "la bolsa de los dineros" que hay para la canonización de Santo Tomás de Villanueva, de su misma Orden, con facultades para obligar a todos aquellos hermanos de dicha Orden, que hubiesen recibido directamente o a través de otros, limosnas o dineros destinados a este fin, para restituir a lo que estén obligados por casusa de la canonización del mismo Santo Tomás, y dar cuentas de lo recibido ${ }^{60}$.

${ }^{56}$ ACA, CA, leg. 743, n ${ }^{\circ}$ 55. Antigua catalogación, AGS, Estado, leg. 3032; texto, en CODOIN, t. V, pp. 135-137; BNM, ms. 3098, fols. 669-671; ej. impreso, en Ibid, V.E., 196/71; otro ejemplar, en RAH, Col. SyC, T-58, fols. 135-136.

${ }^{57}$ ACA, CA, legs. 693, no 25/1 y 2; leg. 726, no 104/4; leg. 729, n 30/2.

58 Series Actorum omnium in Canonizatione $S$. Thomae a Villanova, cognomento eleemosynarii..., Romae 1658, bien descrita por el P. Santiago Vela, en Ensayo, o.c., t. I, pp. 299-300; BAR, Roma, ms. 192, cc. 1r-144v.

${ }^{59} \mathrm{ACA}, \mathrm{CA}$, leg. $745, \mathrm{n}^{\circ} 1 / 1$.

${ }^{60}$ Bullarium Ordinis Sancti Augustini, t. VII (1644-1669), Romae 2002, nº 435, ed. de C. Alonso. 
- Roma, 18 de febrero de 1659. Bula al asistente general fray Andrés Aznar. Se le encomienda ver "la bolsa de dineros" formada para la canonización de Santo Tomás de Villanueva, y exija, con las oportunas facultades, que los fondos que allí encontrase, lo envíe a su vicario general u otro superior legítimo de dicha Orden, con el fin de terminar con el censo impuesto en el convento de San Agustín de Roma para sufragar los gastos que se han hecho con motivo de dicha canonización ${ }^{61}$.

- Roma, 8 de abril de 1659. Bula al asistente general fray Andrés Aznar. Habiendo sido nombrado en otro tiempo juez y comisario en asuntos de los fondos y deudas relacionados con motivo de la canonización de Santo Tomás de Villanueva, se le concede ahora facultad para reclamar todas las causas concernientes a lo dicho anteriormente, que estén pendientes e incluso ya instruidas ante cualquier juez, para que pueda terminarlas en conformidad con las primeras facultades que se le concedieron ${ }^{62}$.

Con este preámbulo de las facultades concedidas al padre asistente general se puede comprender mejor la carta que don Gaspar de Sobremonte escribe desde Roma a Felipe IV, el 28 de marzo de 1659, en la que le explica la buena actuación que el P. Aznar había tenido en relación al dinero correspondiente a la canonización de Santo Tomás, evitando una nueva demora o suspensión sine die del proceso; también apunta el interés personal del papa en el tema de la canonización y el conocimiento que tenía Alejandro VII del asunto del dinero:

"Señor. He dado cuenta a vuestra majestad del modo en que se celebró la canonización de Santo Tomás de Villanueva y el gusto y ostentación con que su santidad intervino en ella y de lo que el padre asistente de España trabajó en orden a que por falta de dinero no quedase suspendida tan santa obra con riesgo de que introduciéndose otra canonización quedase ésta olvidada, o suspendida por mucho tiempo, y que para este efecto con su buena maña y persuasiva labia movía a los padres italianos a que suministrasen toda la caridad necesaria tomándola a censo de los bienes y rentas del convento de San Agustín de esta corte [Roma] con asenso pontificio y con cláusulas precisas de que si hubiese de librar al convento dentro de ciertos término, y ahora puedo decir a vuestra majestad que habiendo reconocido su beatitud el descuido con que en esta materia procedían los padres de España, y que, no solamente no venía el dinero y aún al mismo convento pero ni aun esperanzas de que viniese, comenzó a aprestar al padre asistente de San Agustín de Roma, que tratando de la

\footnotetext{
${ }^{61} \mathrm{Ibid}, \mathrm{n}^{\circ} 440$.

${ }^{62} \mathrm{Ibid}, \mathrm{n}^{\circ} 450$. Agradecemos a los PP. Isaías del Río y Laureano Manrique la ayuda prestada.
} 
redención de los censos y habiéndose ido entreteniendo en los aprietos con varias dilatorias últimamente su santidad ha tomado resolución de que el padre asistente pasa a España a la recuperación y conducción de este dinero para lo cual le ha despachado breve en amplísima forma como verá vuestra majestad por su tenor cuando se presente en ese Supremo Consejo de Aragón..."

Y efectivamente pocos años después se llegó al arreglo definitivo en el Capítulo celebrado en el convento de San Sebastián de Épila (Zaragoza), en abril de 1663, bajo la presidencia del padre fray Tomás de Figuerola, buen conocedor de este asunto, donde se ve que realmente los agustinos de la Provincia de Aragón eran conscientes de la deuda con los hermanos de Roma y querían acabar cuanto antes con la deuda contraída:

"Propuso nuestro muy reverendo P. Presidente, el maestro Fr. Tomás Figuerola que debiendo la Provincia a la canonización de Santo Tomás siete mil ochocientos cincuenta escudos, es a saber, seis mil al convento de San Agustín nuestro padre de la ciudad de Zaragoza, y la restante cantidad al convento de nuestro padre San Agustín de Barcelona, que arbitró la tomaría para pagar enteramente al convento de Roma toda la cantidad que se le debe. Y al convento de Zaragoza todos los réditos de los seis mil escudos, que son trescientos escudos cada año. Y resolvieron que para pagar lo que se debe al convento de Roma se tome el dinero que se halla hoy en el arca del santo, que son seiscientos y ocho escudos, y que se haga un repartimiento entre los conventos de la Provincia de mil cuatrocientos sesenta escudos, y que éstos se enviasen a Roma dentro de seis meses, extinguiendo totalmente la deuda, pagando juntamente el convento de San Agustín nuestro padre de Valencia los mil ducados que debe. Y para pagar los réditos de los seis mil escudos que ha pagado el convento de San Agustín nuestro padre de Zaragoza y se ha cargado, se colecten trescientos escudos cada un año sin tocar los ciento y doce escudos que la colecta ordinaria y antigua que tiene hecha la Provincia repartiendo los trescientos escudos entre todos los conventos de la Provincia según la forma y cantidad que va señalada en los papeles que tiene entregado el muy reverendo definitorio a nuestro muy reverendo padre Presidente" ${ }^{\circ 4}$.

\footnotetext{
${ }^{63}$ ACA, CA, leg. 745, nº 1/5.

${ }^{64} \mathrm{AHN}$, Libro de actas de capitulos de la orden agustiniana en la provincia de Aragón, CODICES, L.569 ff. $21 \mathrm{v}-22 \mathrm{v}$.
} 


\section{APÉNDICE}

Relación de limosnas para la canonización de Santo Tomás de Villanueva de fray Buenaventura Fuster de Ribera en la que anuncia: "Espero en Dios N. S. que muy en breve saldrá segundo papel de las limosnas..."

Desde el punto de vista sociológico es muy interesante el listado por ver las instituciones y personas que aparecen y las cantidades que donaron para la canonización, tanto por la cuantía simbólica de unas limosnas y la esplendidez de otras ${ }^{66}$.

${ }^{65}$ Ejemplar, RAH, Col. SyC, U-11, fols. 316-317; cfr. ACA, CA, leg. 693, no 41 (1657). MATEU Y LLOPIS, F., "La situación monetaria en el Reino de Valencia durante Felipe IV y Carlos II (1621-1700)", en NVMISMA (Madrid), 35 (1958) 33-62; IDEM, "La moneda de los Reinos de Valencia y Mallorca", en Ibid, 147-149 (1977) 123-148; PETIT, R., Nuestras monedas. Las cecas Valencianas, Valencia 1981; ARROYO ILERA, R., Las Monedas Valencianas, Valencia 1984. Glosario de tipos de monedas españolas: https://www.tesorillo.com/otras/medievales.htm.

${ }^{66}$ Las equivalencias de las monedas castellanas fijadas en la pragmática de Medina del Campo, de 13-VI-1497, fueron: 1 duc.= 11 rs. de plata ó 375 mrs.; 1 rs. de plata $=34 \mathrm{mrs}$. El real de vellón fue una unidad de cuenta y 2,5 rs. de vellón equivalían a 1 rs. de plata. 


\section{PATER PAVPERVM}

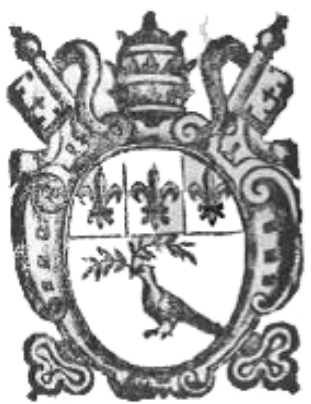

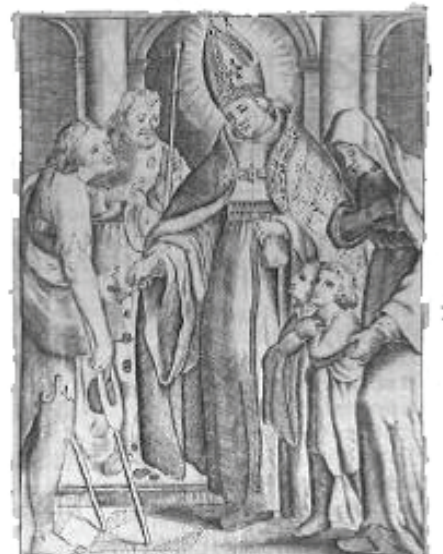

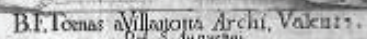

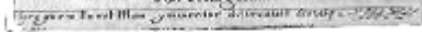

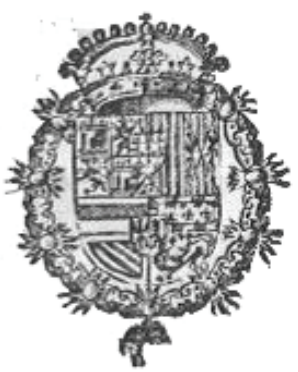

\section{GRATITVD}

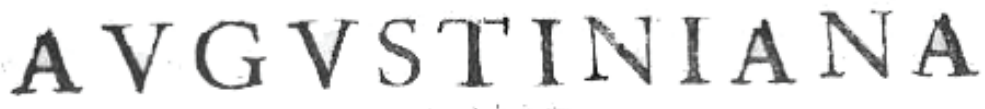
DEVIDA

A LA EMVLACION PIADOSA, DE LAS IGLESIAS, Prelados, Confejos, y Ciudades de coda la Corona de Caftilia, coti pitiendofe en los afectos, y donatiuos, para la canonizacion del ínciico, y Heroico Padte de Pobres, ol Beato Fray Tomas deVillanueua; Arçobifpode Valencia, de la Orden de S.Auguftin Nueftro Padre.

\section{MOTIVADOS}

DE LA REAL, T NVNCA IMITADA LIBERALIDAD DEL REY N S. Siempre Augutto; fiempre Catholico, y licripre Grande.

CONSEGVIDO

Conelcnydado, y defuelo del P. Fr. Buenaventura Fafer de Ribera, Difinidor de la Prouincia Reynos Coronade Aragen, y Procurador General de la Canonizacion del dicho Sanio Arçobrfpode la Orden de S.Augujtin N.P. 


\section{悉 \\ LIMOSNAS.}

La Liberalidad, y Beneficencia de nueftro Gran Monarca cl Rey N.S. diò de linofna $6 . \mathrm{mil}$ ducados de plata, que en vellon fon.

Vellón reales.

La Serenifsima Senora la Madre Sor dna Margarita de San lofeph, del Reat

Connento de la Encarnacion de Madtid, dio de limorna dos Blandones de

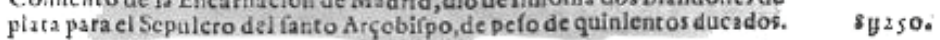

E1 Eminentifsimo Señor Cardenal Ar çobirpodeToledo, Primado de las E'pañas, D. Baltafar de Molco. to y Sasdoual.

1.) Illuttrif.Cabilio de la fanta Iglefia de Toledo.

E) illuftrilis, InquifidorGeneral, Obif pode Plafencia, 100. D. y los de. mas befiores aci Conícjo de por fi dieron a so.D.

J.a Santa Iglefia de Seullla.

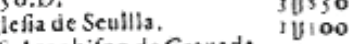

El illultri1. S.Arçobifpo de Granada. z z 200

Elllluttrif S.obifgo de Cuenca.

El lliuftrit.S.Obirpode Zamora.

El tllutril.S.Argob. Oblifpo dz laen.

Fl lliultrif.S. Oblfpo de Cadiz.

El iblultrif.S. Obiapo de Pamplona.

El Illuttril.S. Obifpo deMondoñedo.

El lliluftrif.S.Obilpo de Orenie.

El illuttrif.S Obifpo de Segotia.

El litultril.S Obilpo de Badajoz.

Ei Muy Liluttre Cabildo de la Santa lglefia de Cadiz.

Fl viuy lilutte Cabildo de Murela.

Fl Bisy Illuitre Cabiluo de Zanota.

Ei . vlay lliultre Cabildo de Mondo. ńedo.

El Mitay illut re Cabildo deCalahorra Ei Muy illaltre Cabildo de Obiedo. Fi Muy liutre Cabildo de Badaioz. El Muy llisulte Cabildo de Leon.

La Muy Reiigiofal'rouincia de la An daluzia dela Orden de S. Aguftin.

El Protonotarjo de Angó D.Miguel Baptinta Lanuza.

El Secretario del Confejo de Aragó luas Valero Diaz.

El Secretutio del Conf́ejo Supremo de Inquificion Diego de Villanue. แa.

Efperoen Dios N. S. que muy en breue faldra figundo papel delas limofnas de otros Señores, Prelados, Iglefias. Colleguos. Perfonas particulares, que por labresedad del riem po noje ban podido ajustar.
99 U000.

tigooo

s मо००

$13 \mathrm{HOOO}$

jeys>o

$2=4750$

$\rightarrow>00$

b

El Real Confejo de hazicrida,
El Real Conlejo de Cruzada.

El Real Contejo de Cruzada.

La lunta Real del Relno de Cáfilla. 3H300 uente.

El Excelentid. S. Duque de Medina Celi, y Alcala, CapitanGenetal del mar Ouceano coitas, $y$ exerci. tosde Andalazia.

El Excelentics. Dugue de Arcos, Vi.

U 220

vioo

Us 00

u 200

10100

U5 50

U5 50

U 220

$y^{2} \geq 0$

U200

v:00

$y^{200}$

U100

60476

$\forall 100$

El P.M.Fr. Andres Aznar, de la Pro. uincla de Atagon , de la Orden de San Auguitin,

El Obferuantifsimo Conuento de Au

$2 y 200$

20200

rrey que fue de Napoles. 14100

Excelentif.S.Marques de Villena,

Diquelcalona, Vitrey, y Ca-

El Excelentil.S. Conde de Santife. uan, Marquesdc las Nauas, Conde de Cocentayna, o Virrey que fue de la Cotuna.

La Muy Nobic ciudad de Leon. $\quad$ t60o

L.a Muy Leal ciuad de Cadiz. IH 100

illanueua de losinfantes $s_{8}$ atria de

Los vezinos de la dicha Villa. $\quad 24100$

La Villa de Villahermofa. us 00

GlP.M.Fr.Pedro Morete, Prior del Conuento de $S_{3 n}$ Auguftin de $P^{2}$.

घ300

4300

USso 
